\title{
ANALISIS LAPORAN KEUANGAN USAHA MIKRO KECIL DAN MENENGAH (UMKM) INDUSTRI TAS DAN SEPATU NEW HUNTERIA DENGAN PENDEKATAN STANDAR AKUNTANSI KEUANGAN ENTITAS MIKRO KECIL DAN MENENGAH (SAKEMKM)
}

\author{
Mishelei Loen \\ Program Studi Akuntasi, Fakultas Ekonomi Universitas Krisnadwipayana \\ Kampus Unkris Jatiwaringin \\ email:mishelei.loen@gmail.com
}

\begin{abstract}
Micro, Small and Medium Enterprises (MSMEs) are businesses that have the same owner and manager, capital is provided by an owner or a small group of capital owners. This study examines the New Hunteria Micro Small and Medium Enterprises (MSMEs) in the Depok city. This research uses qualitative research with descriptive type. Data collection in research was obtained through interviews and observations. Based on the results of the study, the Hunteria New Bag and Shoes Industry researchers can conclude that the financial statements made by Micro, Small and Medium Enterprises (MSMEs) are not yet in accordance with the Financial Accounting Standards for Micro, Small and Medium Financial Accounting Standards (SAK EMKM). The New Hunteria Bag and Shoes Industry only makes financial records in the form of records of raw material purchases, sales, employee salaries, and other costs.
\end{abstract}

Keywords: Micro, Small and Medium Enterprises (MSMEs), Financial Reports, SAK EMKM

\section{PENDAHULUAN}

Usaha Mikro Kecil dan Menengah (UMKM) merupakan usaha yang memiliki pemilik sekaligus pengelola yang sama, modal disediakan oleh seorang pemilik atau sekelompok kecil pemilik modal. Sasaran pasar Usaha Mikro Kecil dan Menengah (UMKM) umumnya lokal, meskipun ada yang mengekspor produknya ke luar negeri dan memiliki jumlah karyawan, total asset, dan sarana prasarana yang sedikit. Usaha Mikro Kecil dan Menengah (UMKM) terdiri dari berbagai jenis usaha, seperti perusahaan manufaktur, perusahaan dagang, dan perusahaan jasa (Wuwungan, 2015).

Menurut Ketua Asosiasi Usaha Mikro Kecil dan Menengah Indonesia (Ingratubun, 2019) total kontribusi Usaha Mikro Kecil dan Menengah (UMKM) terhadap produk domestik bruto (PDB) Nasional tahun ini dapat mencapai $65 \%$ atau sekitar Rp2.394,5 triliun. Adapun, realisasi kontribusi Usaha Mikro Kecil dan Menengah (UMKM) terhadap produk domestik bruto PDB Nasional tahun 2018 mencapai sekitar 60,34\%. Meningkatnya proyeksi pertumbuhan kontribusi Usaha Mikro Kecil dan Menengah (UMKM) terhadap PDB sebesar 5\% pada tahun 2019 tersebut memperlihatkan bahwa Usaha Mikro Kecil dan Menengah (UMKM) memberikan peranan yang penting bagi perkembangan perekonomian. Peran penting Usaha Mikro Kecil dan Menengah (UMKM) tidak hanya pada perekonomian Indonesia. Tercatat jumlah Usaha Mikro Kecil dan Menengah (UMKM) di negara maju rata rata mencapai $90 \%$ dari total seluruh unit usaha, dan menyerap 0,67 tenaga kerja dari jumlah pengangguran yang ada (Baas \& Schrooten, 2006).

Tingginya potensi Usaha Mikro Kecil dan Menengah (UMKM) dalam memberikan peran penting bagi perekonomian. Mengakibatkan Usaha Mikro Kecil dan Menengah (UMKM) menjadi lebih unggul dibandingkan dengan usaha besar. Berikut merupakan keunggulan keunggulan Usaha Mikro Kecil dan Menengah (UMKM) dibandingkan dengan usaha besar yaitu: 1. Inovasi dalam teknologi yang telah dengan mudah terjadi dalam pengembangan produk. 2. Berbasis pada sumber daya lokal sehingga dapat memanfaatkan potensi secara maksimal dan memperkuat kemandirian. 3. Kemampuan menciptakan lapangan kerja cukup banyak atau penyerapan tenaga kerja. 4. 
Printed ISSN 2406-7415

e-ISSN 2655-9919

Jurnal Akuntansi \& Bisnis Krisnadwipayana

Vol. 6 No. 2 (Mei - Agustus) 2019

Fleksibilitas dan kemampuan menyesuaikan diri terhadap kondisi pasar dengan cepat dibandingkan dengan perusahaan dalam skala besar yang pada umumnya birokratis. 5 . Terdapat dinamisme manejerial dan peranan kewirausahaan. 6. Dimiliki dan dilaksanakan oleh masyarakat lokal sehingga mampu mengembangkan sumber daya manusia. 7 . Tersebar dalam jumlah yang banyak sehingga merupakan alat pemerataan pembangunan yang efektif (Azrin, 2004).

Keunggulan Usaha Mikro Kecil dan Menengah (UMKM) dibandingkan dengan usaha besar memperlihatkan bahwa peranan UMKM merupakan sentral dalam perekonomian Indonesia. Meskipun peranan UMKM dalam perekonomian indonesia adalah sentral, namun kebijakan pemerintah maupun pengaturan yang mendukungnya sampai sekarang dirasa belum maksimal. Masih banyaknya permasalahan yang dihadapi oleh UMKM membuat kemampuan UMKM berkiprah dalam perekonomian nasional tidak dapat maksimal. Salah satu permasalahan yang dihadapi oleh pelaku UMKM antaralain banyak para pelaku UMKM di Indonesia belum melakukan pencatatan akuntansi sesuai dengan setiap transaksi yang terjadi dan berdasarkan standar akuntansi yang berlaku. Standar akuntansi mempunyai perlakuan akuntansi mulai pengakuan, pengukuran, penyajian maupun pengungkapan, dan tentunya dapat menjadi dasar untuk menyusun laporan keuangan yang andal (Adrianto, Maharani, \& Nuraini, 2017). Dalam pelakasanaannya karena keterbatasan pengetahuan terhadap ilmu akuntansi, rumitnya proses akutansi, dan anggapan bahwa laporan keuangan bukanlah hal yang penting bagi pengusaha UMKM masih banyak pelaku UMKM yang belum menggunakan informasi akuntansi secara maksimal (Said, 2007). Sejalan dengan penelitian (Baas \& Schrooten, 2006) yang menyatakan bahwa mayoritas pelaku UMKM tidak mampu memberikan informasi akuntansi terkait kondisi usahanya.

Informasi akuntansi mempunyai peran yang penting dalam pencapaian keberhasilan usaha termasuk bagi usaha kecil (Megginson, Byrd, \& Megginson, 2000). Informasi akuntansi dalam Usaha Mikro Kecil dan Menengah (UMKM)

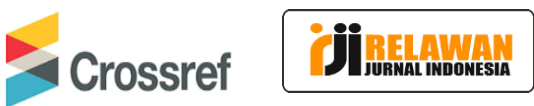

merupakan bagian dari penerapan akuntansi. Pentingnya penerapan akuntansi bagi Usaha Mikro Kecil dan Menengah (UMKM), Ikatan Akuntan Indonesia (IAI) selaku organisasi profesi sekaligus sebagai badan penyusun Standar Akuntansi Keuangan (SAK) membuat Standar Akuntansi Keuangan Entitas Mikro, Kecil dan Menengah (SAK EMKM) yang berlaku efektif per 1 januari 2018, dengan adanya Standar Akuntansi keuangan Entitas Mikro, Kecil dan Menengah (SAK EMKM) diharapkan dapat membantu memudahkan pelaku Usaha Mikro Kecil dan Menengah (UMKM) dalam mengaplikasikan akuntansi pada usaha mereka sehingga dapat dengan mudah menyusun laporan keuangan sesuai dengan standar.

Penelitian ini mengambil objek pada industri tas dan sepatu New Hunteria di kota Depok. Usaha ini merupakan usaha rumahan yang pemasarannya cukup luas. Industri Tas dan Sepatu New Hunteria didirikan oleh Muhamad Ahda pada tahun 1987, industri ini telah terdaftar pada Dinas Perindustrian dan Perdagangan dengan Tanda daftar Industri Nomor:530.053/ Dep.II.05/ Iz.TDI/IX/2006. Industri Tas dan Sepatu New Hunteria merupakan suatu bentuk Usaha Mikro Kecil dan Menengah (UMKM) dimana kegiatan usahanya adalah memproduksi tas dan sepatu sebagai produk utamanya. Tempat yang digunakan untuk kegiatan produksi berlokasi di JL. Siliwangi No. 7 Depok dan JL. Arif Rachman Hakim No. 2 Depok Baru sebagai tempat menjual tas dan sepatu kulit. Selain tas dan sepatu kulit sebagai produknya utamanya, New Hunteria juga menyediakan berbagai macam sandal dan dompet yang terbuat dari kulit asli.

Industri Tas dan Sepatu New Hunteria dalam setiap kegiatan usahanya hanya membuat catatan keuangan berupa catatan pembelian bahan baku, penjualan, beban gaji karyawan, dan biaya lain. Pencatatan laporan keuangan ini di catat berdasar dengan pengetahuan yang di miliki pemilik usaha saja. Hal ini dinyatakan dengan pendapat pemilik Industri Tas dan Sepatu New Hunteria bahwa pencatatan akuntansi rumit, hanya akan menambah pekerjaan, dan membutuhkan waktu dalam penyusunannya. Dan apabila pencatatan akuntansi dilakukan oleh seorang yang sudah ahli 
Printed ISSN 2406-7415

e-ISSN 2655-9919

Jurnal Akuntansi \& Bisnis Krisnadwipayana

Vol. 6 No. 2 (Mei - Agustus) 2019

dibidangnya, maka pemilik harus menambah karyawan dan itu mengakibatkan penambahan beban gaji karyawan. Dalam menentukan laba usaha, pemilik hanya mencatat pendapatan yang diperoleh serta beban yang dikeluarkan, maka akan diketahui berapa laba yang didapat. Kondisi UMKM pada industri tas dan sepatu New Hunteria dalam hal ini belum sesuai dengan Standar Akuntansi Keuangan Entitas Mikro, Kecil, dan Menengah (SAK EMKM). Diharapkan dengan adanya SAK EMKM dengan prinsip kesederhanaan, dapat memberikan kemudahan dalam menyajikan laporan keuangan. Kemudahan untuk UMKM yang dimaksud adalah ketentuan pelaporan yang mudah di mengerti didalam penerapannya.

Menurut penelitian yang dilakukan (Yananto, 2018) sebesar 74,6\% pemilik ataupun pengelola UMKM belum pernah mendapatkan sosialisasi tentang SAK EMKM dan sebanyak 80,4\% UMKM belum melakukan penerapan SAK EMKM pada laporan keuangannya. Penelitian (Amani, 2018), (Savitri, 2018), (Hetika \& Mahmuda, 2018) (Suci \& Rahmini, 2017) menyimpulkan bahwa Pelaku Usaha Mikro Kecil Menengah (UMKM) belum menerapkan SAK EMKM dalam proses akuntansi. Pelaku Usaha Mikro Kecil Menengah (UMKM) hanya membuat catatan sederhana, yaitu hanya terkait dengan pembelian bahan baku serta sebagian biaya yang mereka keluarkan saja. Sehingga sangat sulit untuk mengetahui seberapa besar biaya keseluruhan yang dibutuhkan dalam sekali produksi, dan menentukan laba usaha. Sedangkan Menurut (Salmiah et al., 2018) dalam penelitiannya mengatakan bahwa pemahaman Pelaku UMKM terhadap SAK EMKM masih pada tingkat cukup.

Berdasarkan latar belakang diatas maka dapat ditarik sebuah rumusan masalah tentang bagaimana analisis laporan keuangan pada Usaha Mikro Kecil dan Menengah (UMKM) Industri Tas dan Sepatu New Hunteria dengan pendekatan Standar Akuntansi Keuangan Entitas Mikro Kecil dan Menengah (SAK EMKM) Adapun tujuan dari penelitian ini adalah untuk mengetahui analisis laporan keuangan pada Usaha Mikro

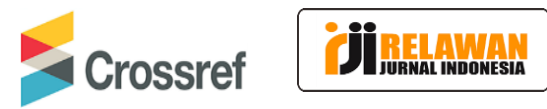

Kecil dan Menengah (UMKM) Industri Tas dan Sepatu New Hunteria dengan pendekatan Standar Akuntansi Keuangan Entitas Mikro Kecil dan Menengah (SAK EMKM), sehingga diharapkan laporan keuangan dapat lebih mudah untuk dipahami, memiliki relevansi, dan daya banding, agar dapat dijadikan acuan bagi pelaku Usaha Mikro Kecil dan Menengah (UMKM) khususnya Usaha Mikro Kecil dan Menengah (UMKM) di kota Depok.

\section{TINJAUAN PUSTAKA}

\section{Usaha Mikro Kecil dan Menengah (UMKM)}

Berdasarkan Undang-Undang Republik Indonesia tentang Usaha Mikro, Kecil, dan Menengah Nomor 20 Tahun 2008 pada bab 1, pasal 1 dijelaskan bahwa yang dimaksud Usaha, Mikro, Kecil, dan Menengah adalah: a) usaha mikro adalah usaha produktif milik orang perorangan dan atau badan usaha perorangan yang memenuhi kriteria usaha Mikro sebagaimana diatur dalam Undang-Undang ini, b) usaha kecil adalah usaha ekonomi produktif yang berdirisendiri, yang dilakukan oleh orang perorangan atau badan usaha yang bukan merupakan anak perusahaan atau bukan cabang perusahaan yang dimiliki, dikuasai, atau menjadi bagian baik langsung maupun tidak langsung dari Usaha Menengah atau Usaha Besar yang memenuhi kriteria Usaha Kecil sebagaimana dimaksud dalam Undang-Undang ini. c) usaha menengah adalah usaha ekonomi produktif yang berdiri sendiri, yang dilakukan oleh orang perorangan atau badan usaha yang bukan merupakan anak perusahaan atau cabang perusahaan yang dimiliki, dikuasai, atau menjadi bagian baik langsung maupun tidak langsung dengan Usaha Kecil atau Usaha Besar dengan jumlah kekayaan bersih atau hasil penjualan tahunan sebagaimana diatur dalam UndangUndang ini.

\section{Standar Akuntansi Keuangan Entitas Mikro Kecil dan Menengah (SAK EMKM)}

Berdasarkan Standar Akuntansi Keuangan Entitas Mikro Kecil dan Menengah (SAK EMKM) (2018:1) dimaksudkan untuk di gunakan oleh Entitas Mikro, Kecil dan Menengah (EMKM) adalah entitas tanpa akuntabilitas publik yang signifikan. Sebagaimana di 
Printed ISSN 2406-7415

e-ISSN 2655-9919

Jurnal Akuntansi \& Bisnis Krisnadwipayana

Vol. 6 No. 2 (Mei - Agustus) 2019

definisikan dalam Standar Akuntansi Keuangan Entitas Tanpa Akuntabilitas Publik (SAK ETAP) yang memenuhi definisi dan kriteria Usaha Mikro, Kecil dan Menengah (UMKM) sebagaimana di atur dalam peraturan perundangundangan yang berlaku di Indonesia, setidaktidaknya selama dua tahun berturut -turut, Standar Akuntansi Keuangan Entitas Mikro Kecil dan Menengah (SAK EMKM) dapat di gunakan oleh entitas yang tidak memenuhi definisi dan kriteria jika otoritas mengizinkan entitas tersebut untuk menyusun laporan keuangan berdasarkan Standar Akuntansi Keuangan Entitas Mikro Kecil dan Menengah (SAK EMKM).

\section{Laporan Keuangan Dalam Standar Akuntansi Keuangan Entitas Mikro Kecil dan Menengah (SAK EMKM)}

Laporan keuangan dalam Standar Akuntansi Keuangan Entitas Mikro Kecil dan Menengah (SAK EMKM) minimun terdiri dari laporan posisi keuangan pada akhir periode, laporan laba rugi selama periode dan catatan atas laporan keuangan yang berisi tambahan dan rincian pospos tertentu yang relevan.

1. Laporan Posisi Keuangan

Laporan posisi keuangan entitas mencakup pos-pos, kas dan setara kas, piutang, persediaan, aset tetap, utang usaha, utang bank, ekuitas.

2. Laporan Laba Rugi

Laporan laba rugi entitas mencakup pos-pos, pendapatan, beban keuangan dan beban pajak. Entitas menyajikan pos dan bagian dari pos dalam laporan laba rugi jika penyajian tersebut relevan untuk memahmi kinerja keuangan entitas.

3. Catatan Atas Laporan Keuangan Standar Akuntansi Keuangan Entitas Mikro Kecil dan Menengah (SAK EMKM) (2018:13) Catatan atas laporan keuangan memuat :

a. Suatu pernyataan bahwa laporan keuangan telah disusun sesuai Standar Akuntansi Keuangan Entitas Mikro Kecil dan Menengah (SAK EMKM).

b. Ikhtisar kebijakan akuntansi .

c. Informasi tambahan dan rincian pos tertentu yang menjelaskan transaksi penting dan material sehingga

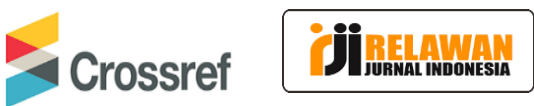

bermanfaat bagi pengguna untuk memahami laporan keuangan.

\section{METODE PENELITIAN}

Penelitan ini menggunakan penelitian kualitatif dengan tipe deskriptif. Pengumpulan data atau informasi yang dibutuhkan dalam penelitian diperoleh melalui wawancara dan observasi. Data kualitatif yang merupakan hasil wawancara yang diperoleh dari pemilik Industri Tas dan Sepatu New Hunteria karena pemilik ini adalah yang mengetahui tentang Industri Tas dan Sepatu New Hunteria dan yang membuat catatatan transaksi sehari-hari. Dokumentasi, berupa dokumen-dokumen yang relevan dengan tujuan penelitian. Sumber data yang diperoleh dalam penelitian ini adalah data sekunder, dimana data yang dikumpulkan adalah berupa gambaran umum, sejarah, visi, misi, serta laporan keuangan Industri Tas dan Sepatu New Hunteria.

\section{HASIL DAN PEMBAHASAN}

Berdasarkan hasil penelitian yang dilakukan dengan cara wawancara didapati hasil, bahwa Industri Tas dan Sepatu New Hunteria hanya membuat catatan keuangan berupa catatan pembelian bahan baku, penjualan, beban gaji karyawan, dan biaya lain. Pencatatan laporan keuangan ini di catat berdasar dengan pengetahuan yang di miliki pemilik usaha saja. Hal ini dinyatakan dengan pendapat pemilik Industri Tas dan Sepatu New Hunteria bahwa pencatatan akuntansi rumit, hanya akan menambah pekerjaan, dan membutuhkan waktu dalam penyusunannya. Dan apabila pencatatan akuntansi dilakukan oleh seorang yang sudah ahli dibidangnya, maka pemilik harus menambah karyawan dan itu mengakibatkan penambahan beban gaji karyawan. Untuk menentukan laba usaha, pemilik hanya mencatat pendapatan yang diperoleh serta beban yang dikeluarkan, maka akan diketahui berapa laba yang didapat.

Berdasarkan hasil penelitian yang dilakukan dengan cara observasi pada pemilik Industri Tas dan Sepatu New Hunteria diperoleh hasil sebagai berikut: (1) Pemilik Industri Tas dan Sepatu New Hunteria hanya membuat catatan 
Printed ISSN 2406-7415

e-ISSN 2655-9919

Jurnal Akuntansi \& Bisnis Krisnadwipayana

Vol. 6 No. 2 (Mei - Agustus) 2019

keuangan berupa catatan pembelian bahan baku, penjualan, beban gaji karyawan, dan biaya lain, pencatatan laporan keuangan di catat di dasari dengan pengetahuan yang di miliki saja. (2) Pemilik Industri Tas dan Sepatu New Hunteria merasa tidak memiliki kemampuan dan ketrampilan di bidang akuntansi, (3) Pemilik Industri Tas dan Sepatu New Hunteria merasa bahwa akuntansi terlalu rumit, (4) Pemilik Industri Tas dan Sepatu New Hunteria merasa sulit untuk menyisihkan waktu dalam hal mencatat transaksi dan menyusun laporan keuangan sesuai dengan Standar Akuntansi Keuangan Entitas Mikro Kecil dan Menengah (SAK EMKM). (5) Pemilik Industri Tas dan Sepatu New Hunteria merasa usaha yang dijalaninya tidak terlalu besar maka tidak perlu dilakukan pencatatan berdasarkan Standar. (6) Dana yang digunakan untuk usaha sering bercampur dengan dana pribadi atau langsung digunakan untuk membeli barang tanpa melakukan pencatatan akuntansi pada laporan keuangan terlebih dahulu.

Laporan keuangan penting dimiliki oleh sebuah usaha sebagai media untuk menginformasikan kondisi keuangan usaha. Bagi pelaku UMKM, akuntansi terlalu rumit untuk diaplikasikan dalam usaha sehingga mayoritas pelaku UMKM hanya melakukan pencatatan sederhana bahkan ada yang tidak melakukan pencatatan keuangan dan masih mencampurkan antara keuangan pribadi dan keuangan usaha.

Laporan Keuangan Usaha Mikro Kecil dan Menengah (UMKM) Industri Tas dan Sepatu New Hunteria

Berdasarkan hasil penelitian, Industri Tas dan Sepatu New Hunteria sebagian besar melakukan pencatatan keuangan secara sederhana dan belum lengkap serta di kerjakan sendiri yaitu di kerjakan oleh pemilik Industri Tas dan Sepatu New Hunteria. Alasan yang dikemukakan oleh pemilik Industri Tas dan Sepatu New Hunteria yaitu tidak ada waktu atau waktu terbatas, rumit, sulit, menurut mereka.

Berbagai catatan keuangan atau laporan keuangan yang di buat dianggap sudah memadai dan cukup di pahami, berkaitan dengan utang piutang, jumlah pesanan atau jumlah penjualan, kapan pesanan harus selesai, jumlah uang kas yang ada, pembayaran gaji pegawai dan keuntungan yang dapat. Dari catatan-catatan tersebut pemilik Industri Tas dan Sepatu New Hunteria hanya mencatat jumlah barang yang di beli dan dijual, gaji, beban dan biaya, namun pencatatan itu hanya sebatas pengingat saja dan tidak dengan format kuhusus. Pemilik Industri Tas dan Sepatu New Hunteria dapat mengetahui jumlah modal akhir setiap tahun yang hampir sama jumlahnya jika di catat dengan sistem akuntansi.

Industri Tas dan Sepatu New Hunteria hanya membuat catatan keuangan berupa:

1. Catatan pembelian,

Pemilik Industri Tas dan Sepatu New Hunteria hanya mencatat berupa catatan pembelian bahan baku seperti: tali, sol, benang, sablonan, bahan, plastic, lem latex, hentex, mika, pen, dan busa setiap bulannya.

2. Catatan penjualan,

Pemilik Industri Tas dan Sepatu New Hunteria hanya mencatat penjualannya setiap transaksi yang terjadi dalam buku baik penjualan kepada pemda kota Depok, agen sepatu, maupun penjualan secara online.

3. Beban gaji karyawan

Pada awal bulan Januari 2019, karyawan Industri Tas dan Sepatu New Hunteria sebanyak 6 pekerja. Yang ditempatkan dicounter sebanyak 2 orang, sedang 4 orang sebagai pengrajin. Gaji yang diberikan oleh pemilik setiap bulannya merupakan gaji bersih

4. Biaya lain-lain.

Biaya lain Industri Tas dan Sepatu New Hunteria berupa biaya konsimsi pegawai, biaya akomodasi dan biaya listrik.

Catatan keuangan ini di catat, didasari dengan pengetahuan yang di miliki pemilik Industri Tas dan Sepatu New Hunteria saja. Ini memperlihatkan bahwa Industri Tas dan Sepatu New Hunteria belum sesuai dengan Standar Akuntansi Keuangan Entitas Mikro Kecil dan Menengah (SAK EMKM) (terlampir pad table 1 sampai dengan 4).

Analisis Laporan Keuangan Industri New Hunteria sesuai dengan Standar Akuntansi Keuangan Entitas Mikro Kecil dan Menengah (SAK EMKM). 
Printed ISSN 2406-7415

e-ISSN 2655-9919

Jurnal Akuntansi \& Bisnis Krisnadwipayana

Vol. 6 No. 2 (Mei - Agustus) 2019

Industri Tas dan Sepatu New Hunteria dalam pelaporan keuangannya hanya membuat catatan pemasukan dan pengeluaran saja, seperti catatan pembelian bahan baku, catatan penerimaan penjualan, catatan gaji karyawan dan catatan beban lain-lain.

Oleh karena itu peneliti merekomendasikan penyusunan laporan keuangan Usaha Mikro Kecil dan Menengah (UMKM) New Hunteria. Tahap-tahap Penyusunan Laporan Keuangan Usaha Mikro Kecil dan Menengah (UMKM) Industri Tas dan Sepatu New Hunteria adalah sebagai berikut :

1. Membuat persamaan dasar akuntansi

Persamaan dasar akuntansi menjelaskan tentang konsep keseimbangan akuntansi melalui rumus matematis, yang menunjukkan bahwa harta (asset) perusahaan berasal dari dua sumber yaitu pemilik perusahaan yang disebut dengan modal (equity) dan bisa juga berasal dari pinjaman yang disebut dengan kewajiban (liabilities). Melalui penyusunan persamaan dasar akuntasi para pelaku UMKM dapat menyusun laporan keuangan.

2. Laporan Laba Rugi (terlampir table 5)

Menurut SAK EMKM laporan laba rugi memasukkan semua penghasilan dan beban yang diakui selama suatu periode. Tabel 5 merupakan laporan laba rugi yang direkomendasikan peneliti. Berdasarkan laporan laba rugi pada Tabel 5 dapat diketahui bahwa Industri Tas dan Sepatu New Hunteria memperoleh laba sebesar Rp $66,998,000$ selama periode bulan Desember 2018

3. Laporan Posisi Keuangan (terlampir tabel 6)

Menurut SAK EMKM laporan posisi keuangan merupakan laporan yang menyajikan informasi tentang aset, liabilitas dan ekuitas suatu entitas pada akhir periode pelaporan. SAK EMKM tidak menentukan format atau urutan terhadap pos-pos yang disajikan. Meskipun demikian, entitas dapat menyajikan pos-pos aset berdasarkan urutan likuiditas dan pos-pos liabilitas berdasarkan urutan jatuh tempo. Table 6 merupakan laporan posisi keuangan yang direkomendasikan peneliti. Laporan posisi

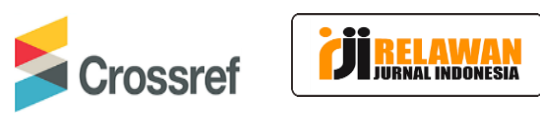

keuangan pada table 6 diketahui bahwa keseluruhan asset usaha Industri Tas dan Sepatu New Hunteria sebesar Rp 202.740.000 yang seluruhnya bersumber dari pemilik tanpa ada pinjaman ke pihak lain.

4. Catatan Atas Laporan Keuangan (terlampir table 7)

Catatan atas laporan keuangan UMKM Industri Tas dan Sepatu New Hunteria dibuat berdasarkan informasi yang didapat dari perusahaan yang kemudian telah diolah oleh peneliti dan disesuaikan dengan kaidah SAK EMKM. Catatan atas laporan keuangan UMKM Industri Tas dan Sepatu New Hunteria berisi pernyataan bahwa laporan telah disusun sesuai SAK EMKM, ringkasan kebijakan akuntansi signifikan yang diterapkan, dan dasar pengukuran yang digunakan dalam penyusunan laporan keuangan.

\section{KESIMPULAN DAN SARAN \\ Kesimpulan}

Setelah peneliti melakukan penelitian pada objek penelitian Industri Tas dan Sepatu New Hunteria di melalui observasi dan interview dan melakukan analisis kemudian peneliti dapat mengambil kesimpulan bahwa Laporan keuangan yang dibuat oleh Usaha Mikro Kecil dan Menengah (UMKM) Industri Tas dan Sepatu New Hunteria belum sesuai dengan Standar Akuntansi Keuangan Standar Akuntansi Keuangan Entitas Mikro, Kecil dan Menengah (SAK EMKM) dimana laporan keuangan terdiri dari Laporan Posisi keuangan, Laporan Laba Rugi, dan Catatan Atas Laporan Keuangan. Usaha Mikro Kecil dan Menengah (UMKM) Industri Tas dan Sepatu New Hunteria hanya membuat catatan pemasukan dan pengeluaran saja

Kendala yang di alami Usaha Mikro Kecil dan Menengah (UMKM) Industri Tas dan Sepatu New Hunteria dalam membuat laporan keuangan dikarenakan Kegiatan Usaha Mikro Kecil dan Menengah (UMKM) Industri Tas dan Sepatu New Hunteria masih fokus pada produksi, sehingga minimnya waktu untuk fokus membuat 
Printed ISSN 2406-7415

e-ISSN 2655-9919

Jurnal Akuntansi \& Bisnis Krisnadwipayana

Vol. 6 No. 2 (Mei - Agustus) 2019

atau mempelajari laporan keuangan yang sesuai standar akuntansi yang berlaku di Indonesia.

Saran

Sebaiknya pengelola Usaha Mikro Kecil dan Menengah (UMKM) Industri Tas dan Sepatu New Hunteria mempelajari bidang akuntansi untuk melakukan pencatatan dan penyusuanan laporan keuangan agar laporan keuangan yang di hasilkan sesuai dengan Standar Akuntansi Keuangan Entitas Mikro Kecil Menengah (SAK EMKM).

Usaha Mikro Kecil dan Menengah (UMKM) Industri Tas dan Sepatu New Hunteria sebaiknya melakukan klasifikasi bukti-bukti transkasi dan mencatatnya dengan rapi agar mempermudah proses pencatatan .

\section{DAFTAR PUSTAKA}

Adrianto, A., Maharani, R., \& Nuraini, F. (2017). PENCATATAN AKUNTANSI PADA USAHA PERTENAKAN AYAM PETELUR. Majalah Ekonomi, XXII(1411), $1-7$.

Amani, T. (2018). Penerapan SAK-EMKM Sebagai Dasar Penyusunan Laporan Keuangan UMKM (Studi Kasus di UD Dua Putri Solehah Probolinggo). ASSETS, 2(2), 12-20.

Azrin, M. (2004). Dampak Ekonomi Pengembangan Usaha Kecil dan Menengah Sektor perdagangan terhadap Perekonomian Kota Bogor.Tesis tidak dipublikasikan.Sekolah Pasca Sarjana Institut Pertanian Bogor (IPB). Bogor.

Baas, T., \& Schrooten, M. (2006). Relationship Banking and SMEs: A Theoretical Analysis *. Small Business Economics, 127-128. https://doi.org/10.1007/s11187006-0018-7

Hetika, \& Mahmuda, N. (2018). PENERAPAN STANDAR AKUNTANSI ENTITAS MIKRO KECIL DAN MENENGAH (SAK EMKM) DALAM MENYUSUN LAPORAN KEUANGAN. Bisnis Terapan, 02, 81-104.

Indonesia, I. A. (2018). Standar Akuntansi
Keuangan Entitas Mikro Kecil dan Menengah (EMKM).

Jusup, A. H. (2014). Dasar-Dasar Akuntansi. Jilid 1. (7th ed.). Yogyakarta: Bagian Penerbitan STIE YKPN.

Megginson, W. L., Byrd, M. J., \& Megginson, L. C. (2000). Small Bussines Management: An Entrepreneur's Guidebook. (Irwin, Ed.) (Third). McGraw-Hill.Boston.

Said, A. \& N. I. W. (2007). Buku Panduan untuk Membangun Akses Pembiayaan bagi Usaha Menengah, Kecil dan Mikro dalam Konteks Pembangunan Daerah. Konrad Adenauer Stiftung.

Salmiah, N., Nanda, S. T., Adino, I., Akuntansi, P. S., Kuning, U. L., \& Riau, P. (2018). PEMAHAMAN PELAKU UMKM TERHADAP SAK EMKM: SURVEY PADA UMKM YANG TERDAFTAR DI DINAS KOPERASI DAN UKM, 2(2), 194-204.

Savitri, R. V. (2018). PENCATATAN AKUNTANSI PADA USAHA MIKRO KECIL DAN MENENGAH ( STUDI PADA UMKM MR . PELANGI SEMARANG ) Keywords: accounting records, UMKM Kata Kunci : Pencatatan Akuntansi , UMKM Corresponding author :, 5(2), 117-125.

Suci, \& Rahmini, Y. (2017). PERKEMBANGAN UMKM ( USAHA MIKRO KECIL DAN MENENGAH ) DI INDONESIA. Cano Ekonomos, 6(1), 5158.

Wuwungan, J. Y. S. (2015). Analisis penerapan standar akuntansi keuangan entitas tanpa akuntabilitas publik atas persediaan pada apotik uno medika. EMBA, 3(4), 498-507.

Yananto, M. P. (2018). PEMETAAN PENERAPAN STANDAR AKUNTANSI KEUANGAN EMKM PADA UMKM DI KOTA TANGERANG SELATAN. Profita, 11(2), 201-217. 
Printed ISSN 2406-7415

e-ISSN 2655-9919

Jurnal Akuntansi \& Bisnis Krisnadwipayana

Vol. 6 No. 2 (Mei - Agustus) 2019

\section{LAMPIRAN}

Tabel IV-1

Catatan Pembelian Bahan Baku Usaha Mikro Kecil dan Menengah (UMKM) Industri Tas dan Sepatu New Hunteria

\begin{tabular}{|c|c|}
\hline Pembelian & Nominal \\
\hline Jan-18 & Rp5,462,000 \\
\hline Feb-18 & Rp5,417,000 \\
\hline Mar-18 & Rp4,546,000 \\
\hline Apr-18 & Rp5,256,000 \\
\hline May-18 & $\mathrm{Rp} 7,758,000$ \\
\hline Jun-18 & Rp5,664,500 \\
\hline Jul-18 & Rp8,105,500 \\
\hline Aug-18 & Rp4,752,000 \\
\hline Sep-18 & Rp3,917,000 \\
\hline Oct-18 & Rp4,184,000 \\
\hline Nov-18 & $\mathrm{Rp} 7,882,000$ \\
\hline Dec-18 & Rp8,056,000 \\
\hline & $\operatorname{Rp} 71,000,000$ \\
\hline
\end{tabular}

Tabel IV-2

Catatan Pembayaran Gaji Usaha Mikro Kecil dan Menengah

(UMKM) Industri Tas dan Sepatu New Hunteria

\begin{tabular}{|c|c|}
\hline & \\
\hline Beban gaji & Nominal \\
\hline Jan-18 & Rp $2,500,000$ \\
\hline Feb-18 & Rp $2,500,000$ \\
\hline Mar-18 & Rp $3,000,000$ \\
\hline Apr-18 & $\mathrm{Rp} \quad 3,000,000$ \\
\hline May-18 & Rp $3,000,000$ \\
\hline Jun-18 & Rp $\quad 6,000,000$ \\
\hline Jul-18 & $\mathrm{Rp} \quad 3,000,000$ \\
\hline Aug-18 & Rp $3,000,000$ \\
\hline Sep-18 & $\mathrm{Rp} 3,000,000$ \\
\hline Oct-18 & $\mathrm{Rp} \quad 2,100,000$ \\
\hline Nov-18 & Rp $2,100,000$ \\
\hline Dec-18 & Rp $2,100,000$ \\
\hline Jumlah & $\operatorname{Rp} 35,300,000$ \\
\hline
\end{tabular}

Sumber : UMKM “New Hunteria”(2019)

Tabel IV- 3

Catatan Penjualan Usaha Mikro Kecil dan Menengah

(UMKM) Industri Tas dan Sepatu New Hunteria

\begin{tabular}{|r|r|}
\hline \multicolumn{1}{|c|}{ Penjualan } & \multicolumn{1}{l}{ Nominal } \\
\hline & Rp16,962,000 \\
\hline Jan-18 & Rp20,867,000 \\
\hline Feb-18 & Rp10,056,000 \\
\hline Mar-18 & Rp12,466,000 \\
\hline Apr-18 & Rp18,308,000 \\
\hline May-18 & Rp12,114,500 \\
\hline Jun-18 & Rp19,305,500 \\
\hline Jul-18 & Rp11,400,000 \\
\hline Aug-18 & Rp12,217,000 \\
\hline Sep-18 & Rp11,634,000 \\
\hline Oct-18 & Rp20,882,000 \\
\hline Nov-18 & Rp18,531,000 \\
\hline Dec-18 & Rp184,743,000 \\
\hline & Sumber: UMKM Hunteria”(2019) \\
\hline
\end{tabular}

Tabel IV- 4

Catatan Biaya Lain-lain Usaha Mikro Kecil dan Menengah (UMKM) Industri Tas dan Sepatu New Hunteria

\begin{tabular}{|r|r|}
\hline \multicolumn{1}{l|}{ Beban lain-lain } & \multicolumn{1}{l}{ Nominal } \\
\hline Jan-18 & Rp500,000 \\
\hline Feb-18 & Rp450,000 \\
\hline Mar-18 & Rp360,000 \\
\hline Apr-18 & Rp310,000 \\
\hline May-18 & Rp330,000 \\
\hline Jun-18 & Rp350,000 \\
\hline Jul-18 & Rp370,000 \\
\hline Aug-18 & Rp370,000 \\
\hline Sep-18 & Rp210,000 \\
\hline Oct-18 & Rp330,000 \\
\hline Nov-18 & Rp340,000 \\
\hline
\end{tabular}




\begin{tabular}{|c|c|}
\hline Dec-18 & Rp775,000 \\
\hline Jumlah & Rp4,695,000 \\
\hline
\end{tabular}

Tabel IV- 5

Rekomendasi Laporan Laba Rugi Usaha Mikro

Kecil dan Menengah (UMKM)

Industri Tas dan Sepatu New Hunteria

Per 31 Desember2018

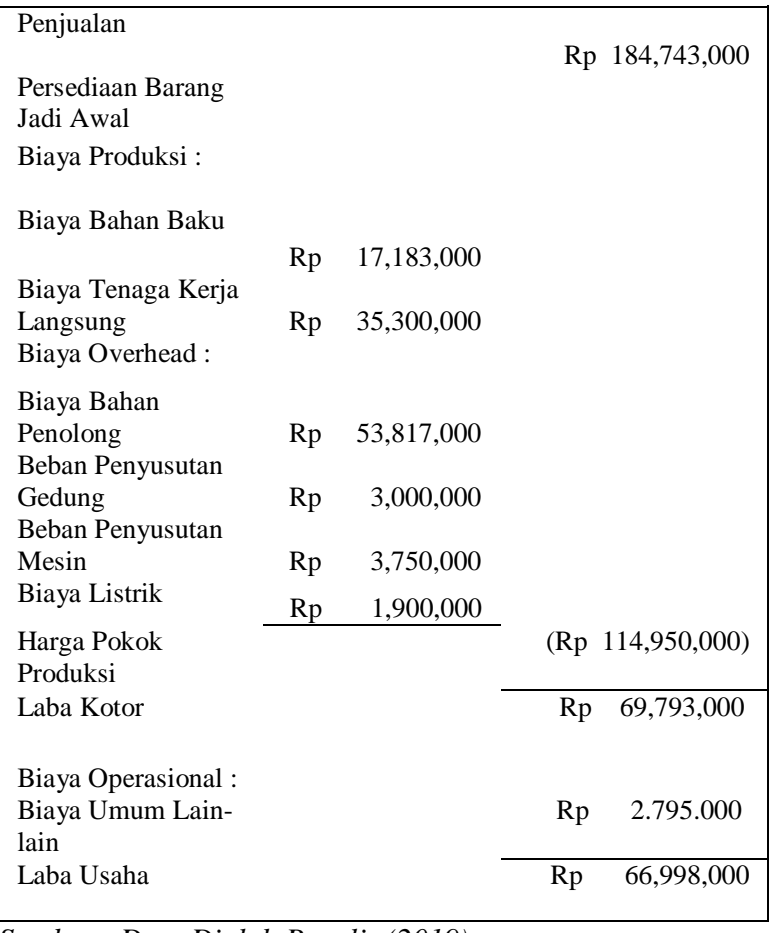

Sumber : Data Diolah Penulis (2019)

Tabel IV- 6

Laporan Posisi Keuangan

Usaha Mikro Kecil dan Menengah (UMKM) Industri Tas dan Sepatu New Hunteria Per 31 Desember 2018

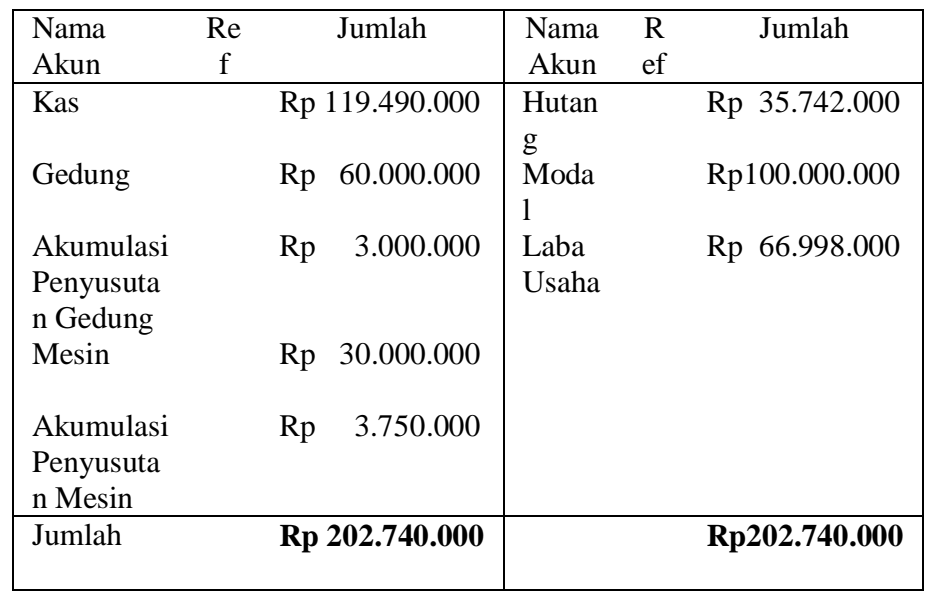

Sumber : Data Diolah Penulis (2019)

Tabel IV- 7

Rekomendasi Catatan Atas Laporan Keuangan Usaha Mikro Kecil dan Menengah (UMKM) Industri Tas dan Sepatu New Hunteria Per 31 Desember 2018

\begin{tabular}{|c|c|}
\hline 1 & $\begin{array}{l}\text { UMUM } \\
\text { Usaha Mikro Kecil dan Menengah (UMKM) } \\
\text { Industri Tas dan Sepatu New Hunteria telah } \\
\text { terdaftar pada Dinas Perindustrian dan Perdagangan } \\
\text { dengan Tanda daftar Industri Nomor:530.053/ } \\
\text { Dep.II.05/ Iz.TDI/IX/2006. Industri Tas dan Sepatu } \\
\text { New Hunteria didirikan pada tahun } 1987 \text { yang } \\
\text { beralamat di JL. Siliwangi No. 7. Usaha Mikro Kecil } \\
\text { dan Menengah (UMKM) Industri Tas dan Sepatu } \\
\text { New Hunteria dalam bidang pembuatan sepatu. } \\
\text { Usaha Mikro Kecil dan Menengah (UMKM) } \\
\text { Industri Tas dan Sepatu New Hunteria telah } \\
\text { memenuhi Kriteria sebagai Entitas mikro, kecil dan } \\
\text { menengah sesuai UU Nomor } 20 \text { Tahun 2008. }\end{array}$ \\
\hline 2 & $\begin{array}{l}\text { IKHTISAR KEBIJAKAN AKUNTANSI } \\
\text { a. Standar Akuntansi Keuangan Entitas Mikro, } \\
\text { Kecil dan Menengah (SAK EMKM) pada } \\
\text { Usaha Mikro Kecil dan Menengah (UMKM) } \\
\text { Industri Tas dan Sepatu New Hunteria belum } \\
\text { memenuhi standar entitas mikro, kecil } \\
\text { menengah. } \\
\text { b. Pernyataan Kepatuhan Terhadap Standar } \\
\text { Akuntansi Keuangan Entitas Mikro, Kecil dan } \\
\text { Menengah (SAK EMKM) Usaha Mikro Kecil } \\
\text { dan Menengah (UMKM) Industri Tas dan } \\
\text { Sepatu New Hunteria menyatakan bahwa } \\
\text { laporan keuangan 2018 belum sesuai dengan } \\
\text { Standar Akuntansi Keuangan Entitas Mikro, } \\
\text { Kecil dan Menengah (SAK EMKM). } \\
\text { Dasar Penyusunan Laporan Keuangan Laporan } \\
\text { Keuangan Usaha Mikro Kecil dan Menengah } \\
\text { (UMKM) Industri Tas dan Sepatu New } \\
\text { Hunteria terdiri dari catatan pembelian, catatan } \\
\text { penjualan, catatan gaji karyawan dan beban } \\
\text { lain-lain. } \\
\text { Persediaan } \\
\text { Usaha Mikro Kecil dan Menengah (UMKM) } \\
\text { Industri Tas dan Sepatu New Hunteria } \\
\text { melakukan pembukuan pencatatan persediaan } \\
\text { yang menggunakan Masuk Pertama Keluar } \\
\text { Pertama (MPKP) dengan pengukuran sesuai } \\
\text { harga perolehan. } \\
\text { Aset Tetap } \\
\text { Aset tetap dicatat sebesar biaya perolehannya } \\
\text { jika aset tersebut dimiliki secara hukum oleh } \\
\text { entitas. Penghitungan akumulasi penyusutan } \\
\text { belum pernah dilakukan dan masih mencatat } \\
\text { aset berdasarkan harga perolehan awal. }\end{array}$ \\
\hline
\end{tabular}


Printed ISSN 2406-7415

e-ISSN

Jurnal Akuntansi \& Bisnis Krisnadwipayana

Vol. 6 No. 2 (Mei - Agustus) 2019

\begin{tabular}{|c|c|}
\hline & $\begin{array}{l}\text { f. Pengakuan Pendapatan dan Beban } \\
\text { Pendapatan dicatat sebesar nilai wajar atas } \\
\text { pembayaran yang diterima. Pendapatan } \\
\text { langsung diakui sebagai kas sehingga dalam } \\
\text { pencatatanya tidak mencatat pendapatan } \\
\text { melainkan kas. } \\
\text { g. Liabilitas } \\
\text { Liabilitas dicatat sebesar jumlah yang harus } \\
\text { dibayarkan serta pengukuran liabilitas } \\
\text { berdasarkan jumlahh kas yang dikeluarkan } \\
\text { untuk membayar kewajiban perusahaan, } \\
\text { h. Ekuitas } \\
\text { Industri Tas dan Sepatu New Hunteria tidak } \\
\text { mencatat ekuitas pada laporan keuanganya. } \\
\text { Penilaian ekuitas berdasarkan asumsi } \\
\text { persamaan akuntansi untuk mencari ekuitas } \\
\text { yaitu aset dikurangi liabilitas. }\end{array}$ \\
\hline 3 & $\begin{array}{l}\text { KAS } \\
\text { Kas Industri Tas dan Sepatu New Hunteria sebesar } \\
\text { Rp119.490.000 }\end{array}$ \\
\hline 4 & $\begin{array}{l}\text { SALDO LABA } \\
\text { Saldo laba merupakan selisih pendapatan dan } \\
\text { beban Industri Tas dan Sepatu New Hunteria pada } \\
\text { periode } 31 \text { Desember } 2018 \text { sebesar Rp } 66,998,000\end{array}$ \\
\hline 5 & $\begin{array}{l}\text { PENDAPATAN PENJUALAN } \\
\text { Penjualan Industri Tas dan Sepatu New Hunteria } \\
\text { sebesar Rp } 184,743,000\end{array}$ \\
\hline 6 & $\begin{array}{l}\text { BEBAN LAIN-LAIN } \\
\text { Beban lin lain Industri Tas dan Sepatu New } \\
\text { Hunteria sebesar Rp } 4.695 .000\end{array}$ \\
\hline
\end{tabular}


Printed ISSN 2406-7415

e-ISSN 2655-9919

Jurnal Akuntansi \& Bisnis Krisnadwipayana

Vol. 6 No. 2 (Mei - Agustus) 2019

UMKM FAMILY SHOES

NERACA LAJUR

PERIODE 31 DESEMBER 2018

\begin{tabular}{|c|c|c|c|c|c|c|c|c|c|c|c|}
\hline \multirow{2}{*}{$\begin{array}{c}\text { No } \\
\text { Aku } \\
\text { n }\end{array}$} & \multirow{2}{*}{$\begin{array}{l}\text { Nama } \\
\text { Akun }\end{array}$} & \multicolumn{2}{|c|}{ Neraca Saldo } & \multicolumn{2}{|c|}{ Penyesuaian } & \multicolumn{2}{|c|}{ Neraca Saldo Setelah Penyesuaian } & \multicolumn{2}{|c|}{ Laba Rugi } & \multicolumn{2}{|c|}{ Neraca } \\
\hline & & Debit & Kredit & Debit & Kredit & Debit & Kredit & Debit & Kredit & Debit & Kredit \\
\hline $\begin{array}{c}1- \\
110\end{array}$ & Kas & $\begin{array}{l}\mathrm{Rp} \\
119,490,000\end{array}$ & & & & $\begin{array}{l}\mathrm{Rp} \\
119,490,000\end{array}$ & & & & $\begin{array}{l}\mathrm{Rp} \\
119,490,000\end{array}$ & \\
\hline $\begin{array}{c}1- \\
211\end{array}$ & Gedung & $\begin{array}{l}\mathrm{Rp} \\
60,000,000\end{array}$ & & & & $\begin{array}{l}\mathrm{Rp} \\
60,000,000\end{array}$ & & & & $\begin{array}{l}\mathrm{Rp} \\
60,000,000\end{array}$ & \\
\hline $\begin{array}{c}1- \\
212\end{array}$ & $\begin{array}{l}\text { Akumulas } \\
\text { i } \\
\text { Penyusuta } \\
\text { n Gedung }\end{array}$ & & & & $\begin{array}{l}\text { Rp3 } 3,000,00 \\
0\end{array}$ & & $\begin{array}{l}\mathrm{Rp} \\
3,000,000\end{array}$ & & & & $\begin{array}{l}\mathrm{Rp} \\
3,000,000\end{array}$ \\
\hline $\begin{array}{c}1- \\
213 \\
\end{array}$ & Mesin & $\begin{array}{l}\mathrm{Rp} \\
30,000,000\end{array}$ & & & & $\begin{array}{l}\mathrm{Rp} \\
30,000,000\end{array}$ & & & & $\begin{array}{l}\mathrm{Rp} \\
30,000,000\end{array}$ & \\
\hline $\begin{array}{c}1- \\
214\end{array}$ & $\begin{array}{l}\text { Akumulas } \\
\text { i } \\
\text { Penyusuta } \\
\text { n Mesin }\end{array}$ & & & & $\begin{array}{l}\mathrm{Rp} \\
3,750,000\end{array}$ & & $\begin{array}{l}\mathrm{Rp} \\
3,750,000\end{array}$ & & & & $\begin{array}{l}\mathrm{Rp} \\
3,750,000\end{array}$ \\
\hline $\begin{array}{c}2- \\
110\end{array}$ & Hutang & & $\begin{array}{l}\mathrm{Rp} \\
35,742,000\end{array}$ & & & & $\begin{array}{l}\mathrm{Rp} \\
35,742,000\end{array}$ & & & & $\begin{array}{l}\mathrm{Rp} \\
35,742,000\end{array}$ \\
\hline $\begin{array}{c}3- \\
100\end{array}$ & Modal & & $\begin{array}{l}\mathrm{Rp} \\
100,000,000\end{array}$ & & & & $\begin{array}{l}\text { Rp100,000,00 } \\
0\end{array}$ & & & & $\begin{array}{l}\mathrm{Rp} \\
100,000,000\end{array}$ \\
\hline $\begin{array}{c}4- \\
100\end{array}$ & Penjualan & & $\begin{array}{l}\mathrm{Rp} \\
184,743,000\end{array}$ & & & & $\begin{array}{l}\text { Rp184,743,00 } \\
0\end{array}$ & & $\begin{array}{l}\mathrm{Rp} \\
184,743,000\end{array}$ & & \\
\hline $\begin{array}{c}4- \\
200\end{array}$ & $\begin{array}{l}\text { Pembelia } \\
\mathrm{n}\end{array}$ & $\begin{array}{l}\mathrm{Rp} \\
71,000,000\end{array}$ & & & & $\begin{array}{l}\mathrm{Rp} \\
71,000,000\end{array}$ & & $\begin{array}{l}\mathrm{Rp} \\
71,000,000\end{array}$ & & & \\
\hline $\begin{array}{c}5- \\
110\end{array}$ & $\begin{array}{l}\text { Beban } \\
\text { gaji }\end{array}$ & $\begin{array}{l}\text { Rp } \\
35,300,000\end{array}$ & & & & $\begin{array}{l}\mathrm{Rp} \\
35,300,000\end{array}$ & & $\begin{array}{l}\mathrm{Rp} \\
35,300,000\end{array}$ & & & \\
\hline $\begin{array}{c}5- \\
130\end{array}$ & $\begin{array}{l}\text { Beban } \\
\text { penyusuta } \\
\text { n gedung }\end{array}$ & & & $\begin{array}{l}\mathrm{Rp} \\
3,000,000\end{array}$ & & $\mathrm{Rp} \quad 3,000,000$ & & $\begin{array}{l}\mathrm{Rp} \\
3,000,000 \\
\end{array}$ & & & \\
\hline $\begin{array}{c}5- \\
140\end{array}$ & $\begin{array}{l}\text { Beban } \\
\text { Penyusuta } \\
\text { n Mesin }\end{array}$ & & & $\begin{array}{l}\mathrm{Rp} \\
3,750,000\end{array}$ & & Rp $\quad 3,750,000$ & & $\begin{array}{l}\mathrm{Rp} \\
3,750,000\end{array}$ & & & \\
\hline $\begin{array}{c}5- \\
150\end{array}$ & $\begin{array}{l}\text { Beban } \\
\text { Lain-lain }\end{array}$ & $\begin{array}{l}\mathrm{Rp} \\
4,695,000\end{array}$ & & & & Rp $\quad 4,695,000$ & & $\begin{array}{l}\mathrm{Rp} \\
4,695,000\end{array}$ & & & \\
\hline & Saldo & $\begin{array}{l}\mathrm{Rp} \\
320,485,000\end{array}$ & $\begin{array}{l}\mathrm{Rp} \\
320,485,000\end{array}$ & $\begin{array}{l}\mathrm{Rp} \\
6,750,000\end{array}$ & $\begin{array}{l}\mathrm{Rp} \\
6,750,000\end{array}$ & Rp $327,235,000$ & $\begin{array}{l}\mathrm{Rp} \\
327,235,000\end{array}$ & $\begin{array}{l}\mathrm{Rp} \\
117,745,000\end{array}$ & $\begin{array}{l}\mathrm{Rp} \\
184,743,000\end{array}$ & $\begin{array}{l}\mathrm{Rp} \\
209,490,000\end{array}$ & $\begin{array}{l}\mathrm{Rp} \\
142,492,000\end{array}$ \\
\hline & $\begin{array}{l}\text { Laba } \\
\text { Usaha }\end{array}$ & & & & & & & $\begin{array}{l}\mathrm{Rp} \\
66,998,000\end{array}$ & & & $\begin{array}{l}\mathrm{Rp} \\
66,998,000\end{array}$ \\
\hline & & & & & & & & $\begin{array}{l}\mathrm{Rp} \\
184,743,000\end{array}$ & $\begin{array}{l}\mathrm{Rp} \\
184,743,000\end{array}$ & $\begin{array}{l}\mathrm{Rp} \\
209,490,000\end{array}$ & $\begin{array}{l}\mathrm{Rp} \\
209,490,000\end{array}$ \\
\hline
\end{tabular}

